\title{
ÁDÁM Boóc * \\ The Reform of the Legal Regulation of Arbitration in Austria with Special Emphasis on the Appointment and Challenge of Arbitrators
}

\begin{abstract}
This study deals with some particular features of commercial arbitration in Austria. The legal framework of arbitration in Austria was changed with an effect of 1st July, 2006, as the Austrian Parliament passed the Schiedsrechts-Änderungsgesetz 2006 in December 2005. This act was proclaimed on the 13th January 2006 and entered into force 1st July in spite of the planned date of 1st January. After having described the significance of arbitration in Austria the author pays special attention to the topic of appointment and challenge of arbitrators. The author compares the rules of the valid Austrian act with the provisions of UNCITRAL Model Law adopted on 21st June, 1985. The author highlights some cases from the legal practice which are considered relevant in the present issue. Finally the author summarizes the provisions of the rules of procedure of International Arbitral Centre of the Austrian Federal Economic Chamber from the point of view of appointment and challenge of arbitrators, which rules have been effective also since 1st July, 2006.
\end{abstract}

Keywords: arbitration, international arbitration, Austria, appointment and challenge of arbitrators.

I.

The settlement of legal disputes in Austria by arbitration looks back to a long past. It is not only the domestic arbitration, which possesses significant traditions in Austria but the place of numerous international commercial arbitration proceedings is also Austria, and respectively Vienna. ${ }^{1}$ Of course the role of Austria and its capital deserves to be accentuated in the field of international commercial law as well. From the aspect of our subject we have to refer before all to the organization of UNCITRAL, Vienna, furthermore to the International

"Junior Research Fellow, Institute for Legal Studies of the Hungarian Academy of Sciences, H-1014, Budapest, Országház u. 30., Hungary

E-mail: adambooc@hotmail.com

1 In relation to earlier Austrian domestic and international arbitration regulation see: Fasching, H. W.: Schiedsgericht und Schiedsverfahren im österreichischen und im internationalen Recht. Wien, 1973. 
Arbitral Centre of the Austrian Federal Economic Chamber (Das Internationale Schiedsgericht der Wirtschaftskammer Österreich). ${ }^{2}$

International commercial practice esteems Vienna as a well-known seat of arbitration along with several other cities-e.g. Paris, Stockholm-, and this sort of psychological circumstance provided that contracting parties often do choose Vienna as the court of arbitration. ${ }^{3}$ The people's democratic states with socialist systems have been also stipulated Austria as the place of arbitration, the reason for this can be identified in the traditional political independence of Austria. ${ }^{4}$ According to the survey conducted in the 1980's on the arbitral practice of the International Chamber of Commerce, Paris (ICC) with the examination of 90 cases it has been determined that also in the cases of the ICC companies from both Eastern and Western Europe had chosen the law of Austria 9\% of the cases and Austria as the place of arbitration $7 \%$ of the cases. ${ }^{5}$ We have to regard these numbers as significant in the light of the fact that the ICC has its seat in Paris and therefore the place of proceedings of international arbitration is in most cases Paris.

In the era of socialism the Austrian arbitral practice had played a significant role in Hungarian business life, as well. ${ }^{6}$ Numerous Hungarian companies had stipulated the jurisdiction of the Austrian Federal Economic Chamber in their foreign trade contracts. ${ }^{7}$ At this point we cannot avoid to mention the 1982 cooperation agreement on the field of commercial arbitration concluded between the Austrian Federal Economic Chamber and the Hungarian Chamber of Commerce and Industry (formerly known as Hungarian Chamber of Commerce). The first amendment to the cooperation agreement was made in 1990 and its text currently in force was determined 11th June 1998. This agreement allowed

${ }^{2}$ In relation with the centre of UNCITRAL in Vienna see: www.uncitral.org. In relation of the Court of Arbitration attached to the Austrian Federal Economic Chamber-which court of arbitration we will investigate in detail later on-see: www.wko.at/arbitration.

3 See also: Berger, K. P.: International Economic Arbitration in Germany: A New Era. Arbitration International, 8 (1992) 103.

${ }^{4}$ See: Melis, W.-Strohlbach, H.: East-West Arbitration. In: Sanders, P. (ed.): Yearbook of Commercial Arbitration, VII (1982) 403.

5 See: Third Seminar on East-West Arbitration: (Paris, December 6-8, 1983) Journal of International Arbitration, 1 (1984) 85-86.

${ }^{6}$ On Middle and Eastern European arbitration in general see: Horváth, É.: Választottbíráskodás Közép- és Kelet-Európában (Arbitration in Middle and Eastern Europe). Külgazdaság Jogi Melléklete, 4 (1994) 49-59.

7 See: Leloczky, K.: East-West Arbitration: A Practitioner's Viewpoint from Hungary. Arbitration International, 4 (1988) 267. 
arbitral proceedings between Austrian and Hungarian business organizations by the application of the UNCITRAL sample code of conduct. The agreement includes a sample arbitration clause, as well, which stipulates the appointment of one or three arbitrators. From the aspect of our subject the appointing body in the agreement has an emphasized significance, since in the statement of claim shall be filed to the appointing body and also this body will proceed in the appointing of the arbitrators as well. According to the agreement, in the case the dispute arises between parties with seats in Austria and Hungary, and the claimant-or counter-claiming defendant-has its seat in Hungary, the Federal Chamber in Vienna shall be the appointing body. In case the the claimant-or counter-claiming defendant-has its seat in Austria, the Hungarian Chamber of Commerce and Industry shall proceed. In case parties with seats in Austria or Hungary have a legal dispute with a person of any kind from a third country, the president of the Federal Economic Chamber in Vienna shall be the appointing body if one of the parties' seat is in Austria, furthermore the president of the Hungarian Chamber of Commerce and Industry shall proceed in the appointment if one of the parties have its seat in Hungary. ${ }^{8}$

From the aspect of the appointment of the arbitrators Article 3 of the agreement deserves special attention according to which the Court of Arbitration attached to the Hungarian Chamber of Commerce and Industry and the Arbitral Centre of Austrian Federal Economic Chamber owns one common list of arbitrators, onto which each party may designate up to 21 persons eligible for the arbitrator's position, of whom 7 should be neither Austrian nor Hungarian citizen. This list is obligatory for the appointing body, yet it is only recommendatory for the parties to the dispute, however only persons who signed the arbitral contract attached to the agreement may act as arbitrators. ${ }^{9}$ The provision in connection with the arbitrator's nationality has a significance in order to guarantee the impartiality and independence of the proceeding persons, moreover it is for the same reason that the appointment is divided as written above between the two chambers.

The agreement concluded in $7^{\text {th }}$ September 1984, Vienna does also provide support for the significant role of the Austrian arbitration during the 1980s. This agreement-which was created in a five year period of preparation and harmonizing-with the help of the recommended arbitration clause allowed American and Hungarian companies and enterprises to designate Vienna as the

8 For more on this see: Horváth, É.-Kálmán, Gy.: Nemzetközi eljárások joga - A kereskedelmi választottbíráskodás (Law of International proceedings-Commercial Arbitration). Budapest, 2003. 139-140.

9 For the text of the Agreement visit: http://www.mkik.hu/index.php?.id=54. 
place of proceedings and the arbitral rules of UNCITRAL (Arbitration Rules of the United Nations Commission on International Trade Law, UNCITRAL Rules) as the law of procedure. From the aspect of our subject it deserves special stressing that in accordance with the clause, in case the parties cannot agree on the appointment of the arbitrators, the chairman of the arbitral centre of the Austrian Federal Chamber shall appoint the arbitrators, from a list collectively set up by the American Arbitration Association and the Hungarian Chamber of Commerce. On this list one can only find highly reputable judges and attorneys of different nationalities who were not coming from either the United States or Hungary. This provision served the assurance of the independence and impartiality of the arbitral body. The optional appliance of the recommended clause can be described as a significant element of the agreement, thus parties could agree on other kinds of arbitral arrangements. ${ }^{10}$

The principle rules of arbitration in Austria can be found among rules providing on standard civil procedures-similarly to some other European legal systems, like that of Germany. ${ }^{11}$ The Austrian law on civil procedures, the Code of Civil Procedure, the Zivilprozessordnung (hereinafter referred to as ZPO) entered into force $1^{\text {st }}$ January $1898 .{ }^{12}$ The introduction of the ZPO was taken care of by the Einführungsgesetz zur Zivilprozessordnung (Gesetz vom 1. 8. 1895 betreffend die Einführung des Gesetzes über das gerichtliche Verfahren in bürgerlichen Rechtsstreitigkeiten) adapted on the $1^{\text {st }}$ August 1895. The first significant reform of the rules of arbitration was carried out by the 1983 civil procedure novella. Before this only one editorial correction had been made in 1929 in relation with Paragraph 3 of Article 583. ${ }^{13}$ In the preparation of the reform of 1983-which carries the name Zivilverfahrens-Novelle 1983-

${ }^{10}$ See: American Arbitration Association, Hungarian Chamber of Commerce and Federal Economic Chamber of Austria: Signature of New Agreements to assist Trade Between the United States and Hungary by Providing for Arbitration in Vienna, Vienna, September 7, 1984. Journal of International Arbitration, 1 (1984) 369-370.

${ }^{11}$ It should be noted as well that respectively up to the 2006 reform of the Austrian arbitration law the laws on the jurisdiction and competence of courts of common pleas had had a great significance too. (Jurisdiktionsnorm - Gesetz vom 1. 8. 1895 über die Ausübung der Gerichstbarkeit und die Zuständigkeit der ordentlichen Gerichte in bürgerlichen Rechtssachen.)

${ }^{12}$ For a overview regarding the ZPO see: Fasching, H. W.: Zivilprozessrecht. 2. ed. Wien, 1990; Fasching, H. W.-Konecny, A.: Kommentar zu den Zivilprozessgesetzen. 2. ed. Vienna, 2003; Rechberger, W. H.: Kommentar zur ZPO. 2. ed. Wien, 2000.

${ }^{13}$ For this see: Liebscher, Ch.-Schmid, A.: Arbitration Law in Austria. Journal of International Arbitration, 16 (1999) 25. 
Prof. Iván Szász has played an important role which activity was met with great acknowledgement in Austria. ${ }^{14}$

It is vital to pay attention to the year of the procedure amendment which has made among others even the conclusion of the arbitration contract easier, ${ }^{15}$ since it precedes the UNCITRAL Model Law of 1985. As a result of that, this amendment could not have taken into account the provisions of the Model Law, thus the development of the Austrian arbitration practice had avoided background regulations based on the UNCITRAL Model Law till the year of 2006. According to the opinion of some authors, this Austrian arbitration regulation has adjusted itself only moderately to the demands of international arbitration procedures. ${ }^{16}$ Other authors think that even this Austrian amendment has been created to keep pace with the significant development of the international arbitration after World War Two. ${ }^{17}$

At the same time, the significant American expert, Gary B. Born has the standpoint that this Austrian body of regulation assures the accomplishment of arbitration contracts and the enforcement of the arbitral awards in the appropriate way, furthermore it is also important that the interference of state judicial bodies stays only minimal. ${ }^{18}$

Taking into account the abovementioned the reform of the Austrian arbitration law presented an ever urging demand in the 1990s, the main goal of the reform being the accommodation to the compliance with the provisions of the UNCITRAL Model Law. In 2000 Prof. Walter H. Rechberger from Vienna proposed that the Ludwig-Boltztmann-Instituts für Rechtsvorsorge und Urkundenwesen Institute which was led by him shall set up a workgroup dealing with the reform of arbitration law. The task of this workgroup was to create a draft resolution for part six of the ZPO that contained the arbitration rules. The leader of the workgroup was Prof. Paul Oberhammer from Zurich. Experts from the areas of both practice and theory of arbitration took part in the workgroup. The draft on the reform of the arbitration rules was presented to justice minister Böhmdorfer in 2002 under the title Entwurf eines neuen Schiedsverfahrens-

${ }^{14}$ See: www.ssd.com/files/tbl_s10News/FileUpload44/12373/Szasz.pdf .

${ }^{15}$ See: Niklas, M.: Schiedsverfahren via Internet. Juristische Möglichkeiten der Verfahrensabwicklung via Internet nach der ZPO. http://www.rechtsprobleme.at/doks/ internet-schiedsverfahren-niklas.pdf 2.

${ }^{16}$ Regarding this see especially: Herrmann, G.: The UNCITRAL Model Law-Its Background, Salient Features, and Purposes. Arbitration International 1 (1985) 9.

${ }^{17}$ For this see: Lionnet, K.: The UNCITRAL Model Law. A German Perspective. Arbitration International. 6 (1990) 344.

${ }^{18}$ See: Born G. B.: International Commercial Arbitration. Commentary and Materials. 2. ed. The Hague-Boston-London, $2001^{2} .147$. 
rechts. According to the ministerial motion the goal of the reform was that Austria became an even more attractive seat of arbitration. ${ }^{19}$

The adoption of the draft statute however needed more time. The third official version dates $18^{\text {th }}$ October 2005. The Austrian Parliament passed the Schiedsrechts-Änderungsgesetz 2006 in December 2005 and which was proclaimed on the $13^{\text {th }}$ January 2006 and entered into force $1^{\text {st }}$ July in spite of the planned date of $1^{\text {st }}$ January. ${ }^{20}$

The new arbitration set of rules can be found in Art. 577-618 of the ZPO and includes ten parts: General Rules (Allgemeine Bestimmungen), Arbitration contract (Schiedsvereinbarung), Setting up the arbitral tribunal (Bildung des Schiedsgerichts), Jurisdiction of the Arbitral Tribunal (Zuständigkeit des Schiedsgerichts), Conduct of the Proceedings (Durchführung des schiedsrichterlichen Verfahrens), Arbitral Award and Termination of Proceedings (Schiedsspruch und Beendigung des schiedsrichterlichen Verfahrens), Legal Remedy against the Award (Rechtsbehelf gegen den Schiedsspruch), Recognition and Enforcement of the Arbitral Award (Anerkennung und Vollstreckung von Schiedssprüchen), Special Provisions (Sonderbestimmungen). ${ }^{21}$

The unified set of rules, that is relating to international and domestic arbitration cannot be considered only as the amendment of the existing legal regulations. According to Walter H. Rechberger the new statute is a complete revision of the Austrian arbitration rules based on the UNCITRAL Model Law. In the opinion of Rechberger the provisions of the Model Law were not taken over on a full scale, the Austrian act do follow party different solutions from the Model Law, furthermore in the course of the preparation of the draft reform, numerous foreign bodies of law had been considered as well-thus for example the arbitration laws of Switzerland, England and France. ${ }^{22}$ Nevertheless Austria can be considered as a Model Law Country from the date of $1^{\text {st }}$

19 „....die Stellung Österreichs als Schiedsort noch attraktiver zu machen.“ (to make the status of Austria as place for arbitration more attractive). For the preparation of the reform of the arbitration see also: W. H. Rechberger: Einführung in das neue österreichische Schiedsverfahrensrecht. In: http://www.iwp.or.at/veranstaltungen/unterlagen_2006_ 03_21.pdf 3.

${ }^{20}$ Cf.: Baier, A.-Trofaier, M. T.: Austria. In: Rowley, J. W.-Mendelsohn, Mc. B. (ed.): Arbitration World. Jurisdictional Comparisons. London, 2006 2.18.

${ }^{21}$ These special provisions refer to arbitral proceedings between the undertaker (Unternehmer) and the consumer (Verbraucher) Par. (1) of Art. 617 provides on a theoretical level that in relation with the undertaker and the consumer an arbitral contract may be concluded validly only in existing legal disputes.

${ }^{22}$ See: Rechberger: Einführung in das neue... op. cit. 4-5. 
July 2006 from the point of acts on arbitration since the Austrian arbitration rules are based on the Model Law-similarly to many other legal systems.

II.

Art. 586-591 of Capital 3 of Part 6 of the ZPO (Bildung des Schiedsgerichts) ${ }^{23}$ provides on the setting up of the arbitral tribunal, the nomination and challenge of arbitrators, the reasons for challenges, which provisions we analyse in detail further below, with the comparing to the older regulation and the stipulations of the Model Law. ${ }^{24}$ We will also refer to some cases arisen in the practice in relation of the nomination and challenge of arbitrators. ${ }^{25}$

According to Art. 586 of the ZPO in force parties may agree upon the number of arbitrators freely. In case parties nominate an even number of arbitrators, the arbitrators shall nominate one other arbitrator who will preside of the tribunal. In case parties do not agree otherwise, the number of arbitrators shall be three. This regulation is different from earlier rules and to some extent from the Model Law, as well. The earlier regulation had not contained provisions on the odd number of arbitrators, that is there were no such provisions as a further arbitrator shall be nominated by the arbitrators if they were appointed in an even number. ${ }^{26}$ Evidently, this question has an importance from the viewpoint of the ability to decide of the tribunal. According to Par. 1 of Art. 591 of the invalidated ZPO, in case a majority of votes cannot be achieved, moreover in case there two arbitrators no agreement can be reached, then this fact shall be disclosed to the parties.

\footnotetext{
${ }^{23}$ It is noteworthy that the title of Capital 3 is rather deceptive since the word Bildung means creation yet this same capital contain the rules of challenges of arbitrators as well. This system does correspond with thee terminology of the UNCITRAL Model Law, Capital 3 thereof deals with the setting up of the arbitral tribunal (Composition of the Arbitral Tribunal), as well.

${ }^{24}$ For an overview of the new Austrian arbitration law see: Liebscher, Ch.: The New Arbitration Act 2006. Text And Notes. The Hague, 2006; Zeiler, G.-Steindl, B.: The New Austrian Arbitration Law. A Basic Primer. Wien-Graz, 2006.

${ }^{25}$ With respect to the fact that the later arbitral rules entered into force 1st July 2006, the cases obviously relate to the application of the former set of regulation.

${ }^{26}$ Art. 580 of the invalidated ZPO provided that in case parties did not stipulate on the number of arbitrators in the arbitral contract, nor appointed any arbitrators, then both parties were entitled to nominate one arbitrator and the thus elected arbitrators would appoint the chair of the tribunal.
} 
In accordance with Par. 2 of Art. 591 if Parties did not stipulate any provisions for this case neither in the arbitration contract nor in later written agreements, then any of the parties are entitled to request the otherwise competent (due to the lack of the arbitration clause) state court of justice to determine the invalidity of the arbitration contract or to pronounce that it is invalid in the actual case. It is clear that this older rule could pose a obstacle to a successful arbitration procedure, since in case both parties do nominate only one arbitrators, and the arbitrators could not reach an unanimous decision, then the whole arbitration contract would be invalid and with this, the possibility of the settlement of the case by way of arbitration would be terminated, too.

It should be noted that the Model Law provides only as much as that parties may determine the number of arbitrators freely. Although at the time of the creation of the Model Law there were conceptions on that in the event parties do not determine the number of arbitrators, with the help of a supplementary rule the even number of arbitrators could be avoided. However the final version of Par. 2 of Art. 10 of the Model Law stipulates that if parties cannot agree upon the number of arbitrators, three arbitrators shall proceed in the case. ${ }^{27}$

From a comparative legal point of view we should note that while the Austrian law provides that if parties nominate an even number of arbitrators, the tribunal-for the sake of decisions-making-actually co-opts itself, the Québec Code of Civil Procedure in force since $11^{\text {th }}$ November 1986 which was revised $1^{\text {st }}$ August 2004 and based on the Model Law, does not give such freedom to the parties. According to Art. 941 of the Québec Code of Civil Procedure three arbitrators should compose the tribunal. The text presumes two litigant parties, since it provides that each party shall nominate one arbitrator, and the thus elected arbitrators shall nominate the president of the tribunal.

Art. 587 of the ZPO contains the rules of the nomination of arbitrators. Paragraph 1. includes the principal rule that parties may agree freely upon the arrangements of nomination of arbitrators. It is a significant difference from the provisions of the Model-act that the Austrian law-contrary to Par. 2 Art. 11 of the Model-act-does not include the principle that if not otherwise provided by the parties none shall be excluded on the base of her nationality to proceed as arbitrator.

In case the parties cannot reach an agreement on the nomination of arbitrators, the ZPO's supplementary rules shall apply. In case of a sole arbitrator, the parties cannot agree upon the person of the arbitrator, after the delivery of notice of the arbitral centre the centre will appoint this arbitrator if this requested by

27 See: Binder, P.: International Commercial Arbitration and Conciliation in Model Law Jurisdictions. London, 2005². 103. 
either party. In case an arbitral tribunal proceeds, each party shall nominate one arbitrator and these appointed arbitrators shall nominate the chair of the tribunal. In case more than three arbitrators shall proceed, then each party is entitled to nominate the same number of arbitrators, and the thus elected arbitrators shall elect the chair of the tribunal.

Point 4 of Par. 2 of Art. 587 of the ZPO contains a four-week-long deadline. In case any of the parties do not fully comply with the obligation to nominate the arbitrators within four weeks upon receipt of the written notice serving for this end, or the arbitrators cannot elect the arbitrator to be co-opted within four weeks, then upon request the ordinary state court of justice shall be entitled to appoint this arbitrator. In case the parties agreed upon special procedures on the nomination of the arbitrators, and any of the parties, the arbitrators, or the electoral body-for example an arbitral institute-breaches these rules, or the parties cannot reach and agreement within this special procedure, upon request of any of the parties the state court of justice shall be entitled to appoint the proceeding arbitrators. Thus the supplementary rules of the ZPO apply not only if parties altogether cannot agree on the nomination of arbitrators, but also in case parties stipulate a special procedure to this end, but for some reason the appointment of the arbitrators does not come to end.

It is an important question whether there are any limits to the freedom of the parties in the nomination of arbitrators. The rules of the ZPO-following the provisions of the Model Law-expressly stipulates that parties may agree upon the rules of procedures freely. It can be concluded from the other provisions of the ZPO-and of the Model Law-and it is also supported by legal literature that the nomination procedure determined by the parties cannot breach the minimum requirements of impartiality of arbitrators, moreover they cannot serve as a reason to the contestation of the arbitral award upon ground of the constitution of the tribunal. ${ }^{28}$

(This can be thus recognized as a limit to the freedom of the parties in connection with the procedures of nomination of arbitrators.) Otherwise the regulation would be inconsistent, since in principle it would then allow a procedure which later on would allow the exclusion of arbitrators, or the invalidation of the arbitral award.

In accordance with Point 5 of Par. 1 of Art. 587 of the ZPO the party shall be bound by the arbitrator who was nominated by her after the time the other party received the written notice on the nomination of this arbitrators. (The Model Law does not include such rule.)

${ }^{28}$ See: Power, J.: The Austrian Arbitration Act. A Practitioner's Guide to Sections 577-618 of the Austrian Civil Procedure. Vienna, 2006. 28. 
The Model Law grants a 30 day period to nominate the arbitrators, while the earlier Austrian regulation provided only a significantly shorter, 14 days period in Par. 1, Art. 581 of the ZPO previously invalidated. Although the new arbitration law requires written nominations, the earlier act was somewhat stricter in accordance with formal requirements. Par. 3 of 581 of the invalidated ZPO provided that the notice on the nomination of arbitrators shall be delivered by post or by notary public to the other party. This proceeding is a must in the case of an oral notification on the person nominated as well since the regulation requires written notifications. ${ }^{29}$ This is important because the other party will be in a confirmative position that she is able to make her remarks, objections regarding the person of the nominated arbitrator only after the receipt of the written notice. It is a significant part of the Austrian legal practice that Art. 581 of the older ZPO shall not apply case the arbitration contract expressively determines the name of the arbitrators. ${ }^{30}$

Art. 582 of the earlier ZPO allowed the courts of justice to appoint arbitrators in an unappealable decision in case the parties do not nominate the arbitrators. In accordance with Par. 1 of Art. 583 of the older ZPO parties were required to nominate arbitrators jointly and no agreement were reached in this matter, any of the parties were entitled to request the state court of justice to declare the arbitral contract null and void. The same could be requested if the arbitral contract included the arbitrators by name and any of these arbitrators passed away, were excluded or denounced to proceed in the case, or otherwise failed in performance of her obligations. ${ }^{31}$ Since the former Art. 579 of the ZPO provided that noone is obliged to accept her nomination to the arbitrator's position. For an important reason one could retire from the tribunal even after the acceptance of the nomination.

It should be emphasized that the Austrian legal practice stressed the private legal nature of the legal relationship between the arbitrator and the nominating party and the arbitral contract as well. ${ }^{32}$ According to a legal case arisen in practice, the arbitral contract enters into force between the arbitrators and the parties only when the arbitrators are appointed and they have accepted the

${ }^{29}$ For this see: Fasching, H. W.: Kommentar zu den Zivilprozessgesetzen. Wien, 1971. 761.

${ }^{30}$ See: EvB1 1959/362 (SZ 32/109). Quoted by: Stohanzl, R. (Hrsg.): Zivilprozessgesetze. Wien, $2002^{9} .563$.

${ }^{31}$ It should be noted that only in case the arbitrators were nominated in the arbitral contract would be the later group of cases, namely the death of the arbitrator, her denouncement, denial or delay to comply with her obligations were enough grounds to declare the invalidity of the arbitral contract.

${ }^{32}$ See: Stohanzl: op. cit. 562. 
nomination and from this aspect the nominator person to the arbitrators are irrelevant. ${ }^{33}$

According to Par. 3 of Art. 583 of the old ZPO in case the arbitral contract was concluded in connection with all and every legal disputes arising from the given legal relationship, and the reason because of which the arbitral contract shall be invalidated does not exclude that disputes in the future will be decided by way of arbitration, the court of justice is entitled to pronounce in its verdict the arbitral contract to invalid only in the given case. In the pertinent practice the verdict of court will invalidate the arbitral contract and not the invalidation of its performance-by the reasons given in detail above. At the same time, the arbitral agreement will be invalidated ipso iure in case the arbitral institution designated in the agreement will be closed down by way of a change of law. ${ }^{34}$

It is clear that by the above mentioned old rules of the ZPO it was relatively easy that by difficulties of the nomination of or by problems with the arbitrators, the arbitral contract would be invalidated, that is the possibility of enforcement of one's rights by way of arbitration would be terminated. It should be noted that these rule-on grounds of the old Art. 585. of the ZPO-are permissive in their nature, which means that parties may deviate from them in the arbitral contract or in later written agreements by mutual consent. ${ }^{35}$

Par. 4 of Art. 587 of the ZPO currently in force contains a somewhat special provision which cannot be found either in the Model Law or in the German civil procedural act which was taken into consideration during the preparation of the Austrian rules. This provision states that one has to determine what kind of claim and on what arbitral contract is about to be enforced in the written notice on the nomination of the arbitrator. ${ }^{36}$ Although in practice one can find in many cases even without this rule references to the content of the legal dispute in notices on the acceptance of the nomination, this rule can be practical when there are more arbitral contracts between the parties. According to the practice, this rule should not be interpreted over-extensively. It could be

\footnotetext{
${ }^{33}$ See: OGH 28. 04. 1998 (253/97). The legal case can be found at www.kluwerarbitration.com/caselaw.

${ }^{34}$ See: SZ 21/66, EvB1 1996/130 (SZ 69/773). Quoted by: Stohanzl: op. cit. 565.

${ }^{35}$ It is expedient to refer to the text of Art. 591. of the old ZPO according to which if the arbitrators could not reach a decision, the parties had to be notified, who could request the court of justice to invalidate the arbitral contract.

${ }^{36}$ See: ZPO 587. § (4): Die schriftliche Aufforderung zur Bestellung eines Schiedsrichters hat auch Angaben darüber zu enthalten, welcher Anspruch geltend gemacht wird und auf welche Schiedsvereinbarung sich die Partei beruft.(The written application for the appointment of an arbitrator must also state which claim is being asserted and on which arbitration agreement the party is pleading.)
} 
enough that the type of the claim, moreover the legal relationship on which the claim is based will be described, furthermore it is also satisfactory, if there are references to the document containing the arbitral contract. ${ }^{37}$ In my opinion the designation of the type and nature of the claim can be relevant because they can affect the party in which arbitrator she will appoint

Par. 6 of 587 of the ZPO contains a subsidiary rule, stating that the court of justice may appoint an arbitrator upon the request of either party in the case the nomination of the arbitrator does not come to pass within 4 weeks upon the receipt of the notice by any other reason not discussed above, moreover if within a reasonable period of time the parties fail to nominate the arbitrators according the nomination rules set out by themselves. This subsidiary rule reflects presumably the affections of the new French Code of Civil Procedures, Par. 2 of Art. 1493 thereof contains a similar solution.

Although also the Model Law contains the provision, that either party is entitled to turn to the court of justice or other competent authority if parties did not agree upon the nomination of the arbitrator, moreover if the appointment procedure stipulated by the parties proved to be unsuccessful, the Model Law does not allow the approach of courts of justice in case the procedure agreed upon by the parties does not end successfully in a reasonable time.

To define the term reasonable time-angemessene Zeit-is not an easy task, the appropriate interpretation of this not fully determined legal term is the task of tribunals. According to Jenny Power the first sentence of Art. 6 of the European Convention for Human Rights signed $4^{\text {th }}$ November 1950 in Rome may prove helpful for the interpretation of the term reasonable time. ${ }^{38}$ The first sentence of Art. 6 of the Convention determines the entitlement to a fair and public hearing within a reasonable time by an independent and impartial tribunal established by law as a fundamental right.

I would like to indicate that to the interpretation of the term of reasonable time even the international commercial law can provide some help too. The United Nations Convention on Contracts for the International Sale of Goods (CISG)-which in fact does not deal directly with arbitration questions, yet nolente-volente it has been applied in numerous arbitration procedures as material law-also know the term of reasonable time. ${ }^{39}$ The first paragraph of

${ }^{37}$ See: Power: The Austrian Arbitration... op. cit. 30.

${ }^{38}$ See: Power: op. cit. 30-31.

${ }^{39}$ In relation to the Vienna CISG see: Mádl, F.-Vékás, L.: Nemzetközi magánjog és nemzetközi kapcsolatok joga (International Private Law and Law of International Relationships). Budapest, 1992³ . 378-397; Sándor, T.-Vékás, L.: Nemzetközi adásvétel (International Sale of Goods). Budapest, 2005. 
Art. 43 of the CISG stipulates that the emptor looses his right to rely on the warrant provisions of article 41 or article 42 if he does not give notice to the seller specifying the nature of the right or claim of the third party within a reasonable time after he has become aware or ought to have become aware of the right or claim. In accordance with Point b) of Par. 2 of Art. 64 of the Convention in cases where the buyer has paid the price, the seller loses the right to declare the contract avoided unless he does so in respect of any breach other than late performance by the buyer, within a reasonable time. According to Par. 7 of Art. 587 of the current ZPO in case the party does make the necessary nomination after the commencement of, but before the resolution stating the end of the procedure before the court for the appointment of the arbitrator, and it is proven by this party, then this very procedure will be terminated. This section-in my opinion-emphasizes the party's procedural autonomy in arbitration proceedings. (Nota bene, this provision is not included in the Model Law.)

Par. 8 of Art. 587 of the ZPO provides basis for the court appointing the arbitrator, by stating that the court of justice-during the course of appointment of the arbitrator-should take into account the provisions set out by the arbitral contact of the parties, moreover the circumstances which are needed for the appointment of independent and impartial arbitrators. It is important to emphasize that the ZPO-contrary to the Model Law-does not provide that in case of a sole arbitrator or a tribunal the possibility should be taken into consideration that the appointed arbitrator should have a different nationality from that of the ones which were nominated by the parties. Par. 9 of Art. 587 of the ZPO provides that there is no appeal against the decision of court in the matter of the appointment of the arbitrator.

\section{III.}

The ZPO does contain provisions on the exclusion of arbitrators, yet they do not define the terms independence nor impartiality. The rules on the exclusion basically follow the stipulations of the Model Law, however they are not altogether identical to them. Par. 1 of Art. 588 of the ZPO provides that the person who intends to accept the arbitrator's position shall notify every possible circumstances which would doubt his independence or impartiality of moreover which is in contradiction to any agreement of the parties. The arbitrators are obliged to disclose without delay any such circumstances from the time of 
acceptance of the nomination throughout the whole arbitral proceedings, with the exception of a previous notification to the parties of the circumstances. ${ }^{40}$

The Austrian act does deviate significantly from the Model Law on two points. According to Art. 12 of the Model Law, when a person is sought out for a possible arbitrator nomination, he should reveal any such circumstance which could be sources of well-grounded, justified doubts about his independence and impartiality. It is clear that the obligation to notify applies only when the given person is intended to accept the nomination. This is in correlation with the old text of Art. 579 of the ZPO-to which we have referred to earlier-which paragraph stipulates that no one is obliged to accept the arbitrator's position. According to Austrian law, every other circumstance shall be revealed which could awake doubts about the impartiality and independence, while the Model Law provides such obligation only in case of a justified doubt.

The second section of Art. 588 of the ZPO provides that arbitrator may be challenged only if circumstances exist that give rise to justifiable doubts as to his impartiality or independence, or that he does not possesses the qualifications required by the agreement of the parties. A party may challenge an arbitrator appointed by him, or in whose appointment he participated, only for reasons of which he becomes aware after the participation in the appointment or after the appointment has been made. This later provision clearly takes over the text found in the Model Law. According to certain scientific views, not even the circumstance that the party to the case did not have any knowledge of the ground of challenge because of his considerable negligence would prohibit this party to initiate a challenge. ${ }^{41}$

Since Austrian law itself does not define the terms of independence and impartiality, it is the task of the practice to work out their frames. In general it can be noted that the arbitrator's obligation to notify the parties on the

${ }^{40}$ It is advisable to refer other German text: „\$ 588. (1) Will eine Person ein Schiedsrichteramt übernehmen, so hat sie alle Umstände offen zu legen, die Zweifel an ihrer Unparteilichkeit oder Unabhängigkeit wecken können oder der Parteivereinbarung widersprechen. Ein Schiedsrichter hat vom Zeitpunkt seiner Bestellung an und während des Schiedsverfahrens den Parteien unverzüglich solche Umstände offen zu legen, wenn er sie ihnen nicht schon vorher mitgeteilt hat." (When a person intends to assume the office of an arbitrator, he shall disclose any circumstances likely to give rise to doubts as to his impartiality or independence or which are in conflict with the agreement of the parties. An arbitrator, from the time of his appointment and throughout the arbitral proceedings, shall without delay disclose any such circumstances to the parties unless they have already been informed of them by him.)

${ }^{41}$ For this see also: Thomas, H.-Putzo, H.: Zivilprozessordnung. 25. ed. Munich, 2003. 1036, 5. section. 
partiality and lack of independence is obvious when he has a personal, business or financial interest in connection with the subject of the case, he has substantial previous knowledge in relation with the legal dispute, or has a personal connection to the parties or incidentally to the other arbitrators. ${ }^{42}$

Taking into consideration that the currently normative legal regulation in Austria entered into force $1^{\text {st }}$ July 2006, the consideration of the previous regulation can be important from the aspect of the examination of this question too.

The former Par. 1 of Art. 586 of the ZPO stipulated that against arbitrators one can file motions of challenge on the same grounds as against a state judge. Par. 2 of Art. 586 deviates from the regulation currently in force because it states that the party who participated in the nomination of the arbitrator, may present a motion of challenge against this arbitrator only for reasons of which he becomes aware after the participation in the appointment or after the appointment has been made. As quoted above, the current rules that are based on the Model Law do not include such expressions, however we have to implicitly imply it, since a ground for challenge arises after the appointment, evidently the nominating party may only learn this fact after the appointment.

In Austria, the rules on the challenge of state judges are contained in the jurisdiction act of civil procedures, the Jurisdiktionsnorm (JN). The full title of the act is Gesetz vom 1. 8. 1895 über die Ausübung der Gerichtsbarkeit und die Zuständigkeit der ordentlichen Gerichte in bürgerlichen Rechtssachen. Article 19 of the JN bears the general title of reasons for omission and challenge of judges (Ablehnungsgründe). According to this Article a judge may be challenged if $(i)$ if the judge is excluded from proceedings in cases defined by law, moreover (ii) if there are satisfactory grounds that doubt the impartiality of the judge (Unbefangenheit). The first group can be considered as absolute exclusion grounds after the terminology of Hungarian law-by the Austrian legal practice real grounds of exclusion (Ausschliessungsgrund)-while the later group could be named as relative grounds of exclusion, which is known to Austrian legal practice as grounds of objections (Ablehnungsgrund). (In the followings we will use the terms of Austrian terminology, i.e. exclusion grounds and objection grounds.)

Exclusion rights are contained in Art. 20 of the JN. According to this exhaustive list there is a ground of exclusion against the judge if the judge is party to the case, co-obligor or co-creditor, or obligor of compensation, the spouse or defined relative (step-child, step-parent, adopted child or foster

${ }^{42}$ See: Holtzmann, H. M.-Neuhaus, J. E.: A Guide to the UNCITRAL Model Law on International Commercial Arbitration. Deventer, 1989. 389. 
parent) of the judge is a party to the case, the judge is or was empowered by either party, the judge participated in the making of decision of a lower level court of justice, in connection of which the appeal was filed.

In case of these exclusion grounds the judge, or arbitrator has to be excluded from the proceedings without any examination of his independence of impartiality. Taking into consideration that during the analysis of the exclusions of arbitrators the practice of challenges of state judges can show us important directions, it is practical to examine it too. ${ }^{43}$ According to Austrian practice the prejudice is an obstacle raised by psychological mechanisms to an impartial decision. Single procedural decisions made during the course of proceedings cannot establish a ground for exclusion in general, as far as they allow the appearance of the lack of objectivity. A special relationship to any of the witnesses can also lead to partiality. ${ }^{44}$

Partiality can be determined as well in case one of the parties is a former judge who worked at the same court of justice where the given proceedings are under way. Partiality was established in another case too, where the judge had been a former colleague of one of the parties, and the dispute of the parties was known to him by way of informal meetings. The case can be viewed as particularly interesting where one judge was determined impartial because he shouted at one of the party, after which he left the room without saying goodbye and slamming the door behind him. ${ }^{45}$ The case is somehow more understandable where the judge disclosed his opinion on the case to one of the parties without the hearing of the other party, whereafter the judge declared that he would change his opinion only if the circumstances which he heard would have changed in a significant way-he was deemed not to be impartial. ${ }^{46}$

Naturally there are more cases where the partiality of the judge was not established. For example the judge was not partial in the case where one of the party was a member to an association where there judge himself was a member to, since the judge was not an active member and he had no personal interest in the outcome of the legal dispute. ${ }^{47}$ In an interesting case the judge's impartiality was determined where his individual opinion in a given legal

${ }^{43}$ This opinion is shared by: Power: The Austrian Arbitration... op. cit. 34.

${ }^{44}$ In relation with these cases see: Stohanzl: op. cit. 26-27.

${ }^{45}$ See: LGZ (Landesgericht) Wien, 27. 07.1993 (72.768) and LGZ Vienna, 6. 10. 1992. (69.693). The cases quoted by: Liebscher, Ch.: The Healthy Award. Challenge in International Commercial Arbitration. The Hague-London-New York, 2003. 275.

${ }^{46}$ See: LGZ Wien, 27. 02. 1991 (66.834). Quoted by: Liebscher: op. cit. 275.

${ }^{47}$ See: OGH (Oberster Gerichtshof). 7. 11. 1991 (117). Quoted by: Liebscher: op. cit. 275. 
question was known. ${ }^{48}$ This deserves special attention since in case of such a particular opinion on a very special legal question there is a chance that a case that contains that given legal question will be decided by him according to his particular opinion, that is it is possible that the psychological attitude required for an impartial and objective decision is lacking. As mentioned above, Austrian legal practice required a kind of psychological independence for impartiality as well, that is why it is questionable whether the viewpoints expressed in two legal cases are in full accordance with each other.

It should be noted that in one arbitration case the arbitrator was found impartial in spite of his enraged behaviour. The explanation to this is that the reason for the behaviour of the arbitrator was the conduct of the lawsuit of one of the parties, yet because of the nature of this conduct the behaviour of the arbitrator was deemed acceptable and they saw no reason to determine his prejudice. ${ }^{49}$ Impartiality was found in an other arbitration case where the arbitrator had represented one of the parties in a former lawsuit. ${ }^{50}$

There is a significant difference between grounds of objections and grounds for exclusions in the older Austrian regulation even from the aspect of procedural law. While grounds of exclusion (Ausschliessungsgrund) shall be taken into account by the arbitral tribunal ex officio, the objection grounds (Ablehnungsgrund) are to be examined only if any of the parties presents such motion. $^{51}$

The other significant difference can be seen clearly in one decision of 2005 of the Austrian Supreme Court of Justice (Oberster Gerichtshof). According to the factual background of the case, one of the parties requested the invalidation of the arbitral award of the International Arbitral Centre of the Austrian Federal Economic Chamber brought on $19^{\text {th }}$ February 2004. His contestation included the argument that he learned of a ground of objection only after the delivery of the arbitral award. His petition was denied by the court of first instance, the decision of which was later upheld by the court of appeal. The Supreme Court of Austria has ruled that the petition was receivable, but it was denied on the substance. The Supreme Court expressed the viewpoint that one has to make a difference between grounds of objections (Ablehnungsgrund) and grounds of exclusion (Ausschliessungsgrund). The petition for invalidation of the arbitral award could only be supported by an exclusion ground which

${ }^{48}$ See: OGH 18. 04. 1989 (110). Quoted by: Liebscher: op. cit. 275.

${ }^{49}$ See: LGZ Wien 21. 03. 1989 (41.530). Quoted by: Liebscher: op. cit. 275.

${ }^{50}$ See: OGH 15. 12. $1971(208 / 71)$ The undisclosed verdict is quoted by: Liebscher: op. cit. 276.

${ }^{51}$ More on this: Fasching: Zivilprozessrecht. op. cit. 776. 
came lately to the knowledge of the party, yet a thus lately learned ground of objection cannot establish a claim on invalidation. ${ }^{52}$

It should be noted that in the view of Prof. Walter H. Rechberger the difference between grounds of exclusion and objection is an exploded theory, therefore he deems it appropriate that new arbitration rules avoid such distinction in the future. ${ }^{53}$

We could find ample examples for the judgement of the impartiality of judges and arbitrators in earlier Austrian case law, which should have some affections on the practice developed on the basis of laws currently in force. With attention to both this and the texts of legal regulations currently in force if one is to investigate the questions of impartiality and independence, one obviously has to take into consideration the special circumstances and facts of the given case. ${ }^{54}$

Article 589 of the ZPO in force, contains the rules of exclusion. According to the first paragraph parties may agree upon the rules of exclusion freely, however they have to be mindful of the possibility of the legal remedy of the third paragraph. In case parties do not stipulate the rules of exclusion, then rules in Par. 2 of Art. 589 shall apply. According to these rules, the party who presents the motion of challenge has to file the petition containing the grounds of exclusion to the arbitration tribunal within 4 weeks of obtaining knowledge of the composition of the tribunal or of the ground of exclusion. Should the challenged arbitrator not withdraw from his office, or the other party does not agree with the exclusion, the arbitral tribunal-with the affected arbitrator-shall decide upon the challenge.

Par. 3 of Art. 589 provides that in case the challenge proves unsuccessful, the challenging party may appeal to the court of justice for a decision on the challenge within 4 weeks upon receipt of the decision. There is no appeal against the decision of court. The procedure before the court is no obstacle to the proceedings and decision-making of the arbitral tribunal-the arbitrator challenged included. With attention to the $1^{\text {st }}$ Par. of Art. 589 there is no deviation from the provisions of the Par. 3, not even in case the parties agree upon special procedures of challenge.

The above written rules of the ZPO actually take over the stipulations of the Model Law with the difference that according to the Model Law the motion for challenge shall be presented within 15 days, and the appeal for the court of

${ }^{52}$ See: OGH 26. 1. 2005 OGH 7Ob314/04h. Can be found at http://fremuth-wolf. com/arbaut/newsletter/ index.php?archiv_id=22.

${ }^{53}$ See: Rechberger: Einführung in das neue... op. cit. 10.

${ }^{54}$ See: Power: The Austrian Arbitration... op. cit. 34. 
justice shall be filed within 30 days upon receipt of the declining decision on the challenge.

Previous to the acceptance of the current provisions of the ZPO two professors of the Vienna University, Prof. Peter Böhm and Prof. Ena-Martis Bajons has presented a commentary to the draft statue in their letter of $22^{\text {nd }}$ June 2005 addressed to the Justice Ministry. According to the letter, the rule of Par. 2 of Art. 589 of the ZPO-which allowed the challenged arbitrator to participate in the decision on the challenge-is in contradiction to an important principle of Rechtstaat, that is no one is to decide in one's own case. The authors of the letter intended to take the edge of this critical remark inasmuch that the legal remedy in Par. 3 of Art. 589, the revision by court of justice represents a possibility to correct the decision brought in this peculiar situation. ${ }^{55}$

Although parties are granted with a relatively great freedom in regulating the rules of exclusion, it deserves noting that numerous arbitral institutes, like the Arbitral Centre of the Austrian Federal Economic Chamber presents detailed regulations on relation to which body of the arbitral institution will be entitles to decide in challenge procedures. (We will discuss these rules in details later on.)

We have to note, that Par. 3 of Art. 601 of the new Austrian Arbitration Act follows Par. 3 of Art. 1049 of the German Code of Civil Procedures. The Austrian law provides here that experts appointed by the arbitral tribunal are subject of the stipulations of Art. 588 and Par. 1 and 2 of Art. 589 of the act. This means that the legal institution of exclusion and the challenge procedure apply for experts as well, but with the important difference that Par. 3 of Art. 589-which establishes the legal remedy by court of justice against an unsuccessful motion of challenge-does not apply in the procedure of challenge against experts. ${ }^{56}$ This entire means that the lack of impartiality and independence of experts do not establish a basis for the invalidation of the arbitral award. It is relevant too that this procedure of challenge applies only on experts appointed by the tribunal. Thus private experts of the parties cannot be challenged. The probative value of reports of such experts are to be evaluated appropriately by the proceeding tribunal itself. ${ }^{57}$

Although it is not implied in the text of Par. 2 of 589 expressively that in case no challenge was made before the tribunal, the appeal to a court of justice is excluded in this aspect, international scientific literature argues that the

${ }^{55}$ For a full text see http://www.parlinkom.gv.at/pls/portal/docs/page/pg/ DE/XII/ME/ME_00280_21/ FNAMEORIG_04.

${ }^{56}$ Zeiler-Steindl: The New Austrian Arbitration... op. cit. 64-65.

${ }^{57}$ For this see: Power: The Austrian Arbitration... op. cit. 75-76. 
possible enforcement of claims before a court of justice has to be preceded a motion of challenge before the arbitral tribunal, since the reason for this is to avoid the lengthening of arbitration procedures. ${ }^{58}$

The legal remedy of court of law in connection with the challenge has its goal in the revision of the decision of the arbitral tribunal. It has an increased importance that this petition is to be filed to the court of law within 4 weeks. Because if no appeal was to the court of law within 4 weeks of the receipt of the decision dismissing the challenge, or the court of law denies the petition, then there is no place for a petition which is based upon Par. 2 of Art. 611 of the ZPO and which is aimed at the invalidation of the arbitral award. ${ }^{59}$

It is clear from the above written that the deadline of the filing the remedial appeal in subject of the challenge may be passed only with forfeiture of right. It deserves noting that previous to the framing of the current arbitration regulation there were concepts-not supported in the course of legislation later on-which deemed in inadvisable to tie this deadline to loss of rights. This was reasoned by them-as showed by Christian Koller as well-that the lack of independence and impartiality could mean even the infringement of public order (ordre public), and thus it is iniquitous that in case the missing of the deadline of the appeal to the court of law one cannot contest the arbitral award on this basis. ${ }^{60}$

It is important to emphasize that Par. 3 of Art. 589 of the ZPO includes a rule which cannot be renounced, that is, the civil remedy cannot be excluded in this question. This is in full conformity with Par. 579 of the ZPO, according to which parties may renounce the right of objection only against measures of the arbitral tribunal, if the rules of arbitration of the ZPO allow deviation in relation to this measure, that is there is no right of renouncement in connection with the cogent rules. ${ }^{61}$ The obvious purpose of this rules is the assurance of the neutrality of the arbitration proceedings.

${ }^{58}$ See: Holtzmann-Neuhaus: A Guide to the UNCITRAL... op. cit. 37.

${ }^{59}$ On the basis of Par. 2 of Art. 611 of the ZPO one can request the invalidation of the arbitral award if the setting up of or the composition of the arbitral tribunal was contrary to the approvable agreement of the parties or in contradiction with the provisions of Art. 611 .

${ }^{60}$ See: Koller, Ch.: Das neue österreichische Schiedsrecht - Die wichtigsten Neuerungen des Schiedsräg. 2006 im Überblick. Teil I. Juristische Ausbildung und Praxisvorbereitung. 2005/2006/03. $186^{21}$ p. )

${ }^{61}$ Art. 579 of the ZPO stipulates as follows: „Hat das Schiedsgericht einer Verfahrensbestimmung dieses Abschnitts, von der die Parteien abweichen können, oder einem vereinbarten Verfahrenserfordernis des Schiedsverfahrens nicht entsprochen, so kann eine Partei den Mangel später nicht mehr geltend machen, wenn sie ihn nicht unverzüglich ab Kenntnis oder innerhalb der dafür vorgesehenen Frist gerügt hat." (Where 
The prevention of the tactic to prolong the arbitration proceedings appears basically in two places in the part of Austrian arbitration law discussed here. The rule also supported by the practice of law according to which in the event the party does not present the challenge to the arbitral tribunal, but uses it only in the civil procedure on the invalidation of the arbitral award, then the challenge cannot be accepted, is obviously preventing the vindication of the tactic that a reason for exclusion is in fact used as a "time bomb" by the party and he may use it after the declaration of the arbitral award. Beside that this tactic has its purpose in the prolongation of the proceedings, it is in itself in contradiction with the legal institution of exclusion. In my opinion the legal institution of exclusion should be in relation with the independent and impartial arbitrators proceeding in arbitration procedures, and not with the exploitation of the motion of challenge by a party in a time deemed as favourable for him, when an unfavourable award has been made. Jean-Pierre Ancel-in whose opinion state courts of justice have key roles in impeding tactics aimed at the prolongation of the proceedings-refers to French legal case examples where the lack of independence of arbitrators only appeared in the arbitral award. In this case the motion for exclusion (furthermore for the determination of lack of independence) should be presented to the court which is entitled to decide on the legal redress against the arbitral award. ${ }^{62}$

A further obstacle to tactics aimed at the prolongation of arbitration procedures can be found in Par. 3 of Art. 589 of the current ZPO, according to which the arbitral tribunal may decide the case in the merits even if there is a revision procedure in its course on the decision dismissing the challenge of one of the arbitrators. It is another question of course that the arbitral tribunal may decide to wait with for the decision of the civil court of law, which is especially meaningful if the court of law excludes the arbitrator, since this decision would serve as a ground for the invalidation of the arbitral award. ${ }^{63}$

According to the older-already invalidated-Austrian arbitration rules an arbitral body of the arbitral institution was entitled to decide on the challenge.

the arbitral tribunal has not complied with a procedural provision of this part from which the parties may derogate, or with an agreed procedural requirement of the arbitral proceedings, a party shal be deemed to have waived his right to object if he does not object without undue delay after having become aware of the failure, or within the provided time limit.)

${ }^{62}$ Jean-Pierre Ancel refers to the verdict reached in March 1998 in the Excelsior Film case by the 1st Civil Department of the French Cour de Cassation. See: Ancel, J. P.: Measures Against Dilatory Tactics: The Cooperation Between Arbitrators and the Courts. In: ICCA Congress series no. 9 (Paris/1999). 420.

${ }^{63}$ See also: Power: The Austrian Arbitration... op. cit. 38. 
However there were no civil redresses before state courts against the decision on the challenge during the course of the arbitration proceedings. (This rather strict regulation differs from other Western European state's-like that of Germany-relevant provisions.) In the case however the challenge was dismissed without any grounds, the invalidation of the arbitral award could be requested on the basis of Point 4 of Par. 1 of Art. 595 of the old ZPO. ${ }^{64}$ Although the Supreme Court of Austria took the viewpoint that the grounds listed in Art. 595 of the ZPO, on which the invalidation of the award may be requested, is an exhaustive list, there are such opinions in scientific literature that in case of other severe breaches of procedural rules not listed in Art. 595. of the ZPO the invalidation of the award may be requested by virtue of infringement of public order. ${ }^{65}$ Point 6 of Par. 1 of Art. 595 of the older ZPO included the public order clause, truly not by this definition, yet with the same interpretation. ${ }^{66}$ The prevailing Point 5 of Par. 2 of Art. 611 which deals with the invalidation of the arbitral award expressively contains that the invalidation of the arbitral award may be requested by virtue of its contradiction with the foundations of Austrian legal order, with public order (ordre public) in case the arbitral proceedings were conducted in such a way. ${ }^{67}$

Concerning the invalidation of the arbitral award in the prevailing Austrian law from the aspect of our theme, we have to underline the followings. Par. 1 of Art. 611 of the ZPO provides that by action of civil law only the invalidation of the arbitral award may be requested. The petition may be filed within 3 months upon receipt of the award. In respect of Point 4 of Par. 2 of Art. 611 of

${ }^{64}$ Point 4 of Par. 1 of Art. 595 of the old ZPO contained the following provision: „\$. 595. (1) Der Schiedsspruch ist aufzuheben ... 4. wenn die Ablehnung eines Schiedsrichters vom Schiedsgericht ungerechtfertigt zurückgewiesen worden ist."

${ }^{65}$ See: OGH, 18. 11. 1982 (1983). Quoted and commented by: Liebscher: The Healthy Award. op. cit. 295.

${ }^{66}$ Point 6 of Par. 1 of Art. 595 of the older ZPO basically stipulates on infringement of the principles of Austrian legal order, furthermore that of mandatory applicable legal regulations in relation with the invalidation of arbitrator awards: „\$. 595. (1) Der Schiedsspruch ist aufzuheben ... 6. wenn der Schiedsspruch mit den Grundwertungen der österreichischen Rechtsordnung unvereinbar ist oder gegen zwingende Rechtsvorschriften verstösst, deren Anwendung auch bei einem Sachverhalt mit Auslandsberührung nach $\$ 35$ IPR Gesetz durch eine Rechtswahl der Parteien nicht abbendungen werden kann."

${ }^{67}$ Point 5, Par. 2 of Art. 611 of the current ZPO contains the term of infringement of public order as follows: „611. § (2) Ein Schiedsspruch ist aufzuheben, wenn ... 5. das Schiedsverfahren in einer Weise durchgeführt wurde, die Grundwertungen der österreichischen Rechtsordnung (ordre public) widerspricht." [An award shall be set aside if ... 5. the arbitral proceedings were conducted in a manner that conflicts with the basic principles of the Austrian legal system (ordre public).] 
the ZPO the invalidation of the award may be requested in case the party had not received appropriate notice on the nomination of arbitrators or on the arbitral proceedings, or by other grounds he had been unable to present his case. As noted before, according to Point 4 of Par. 2 of Art. 611 of the ZPO one can contest the arbitral award in case the setting up (Bildung) or composition (Zusammennsetzung) of the tribunal was not in accordance with the law or the acceptable agreements of the parties. ${ }^{68}$ As referred above, in case the challenging party did not appealed to a civil court of justice against the dismissing decision of the arbitral body, or if it was denied by the court of justice, then on this ground on the basis of Point 4 of Par. 2 of Art. 611 of the ZPO he cannot request the invalidation of the arbitral award.

It is important to note that this regulation of the ZPO differs somewhat from the provisions of the Model Law. That is to say Sub-point (iv) of Point a) of Par. 2 of Art. 34 of the Model Law does not only allow invalidation if the establishment or composition of the tribunal did not comply with legal regulations or appropriate stipulations of the parties, but in the case the arbitral proceedings itself were on contradiction with these rules as well. The Austrian ZPO contained this possibility-that is the request of invalidation on grounds of contra legem proceedings-in another place, namely Point 5 Par. 2 of Art. 611 of the ZPO, which was quoted above.

In case Point 4 of Par. 2 of Art. 611 of the ZPO applies-taking into consideration the abovementioned-it is enough to prove that the establishment or composition of the tribunal did not comply with the rules, thus it is unnecessary that all this would have any affection on the decision on merits. ${ }^{69}$ Thus here Austrian law provides significant legal protection for guarantees in relation with the composition of the arbitral tribunal, contrary for example to German law. Namely, Sub-point d. of Point 1 of Par. 2 of Art. 1059 of the German Code of Civil Procedures (Deutsche Zivilprozessordnung) provides that for the request on invalidation of arbitral awards, a presumed affection on the final award of the irregular arbitral proceedings or of irregular composition of the arbitral tribunal is also needed. ${ }^{70}$

${ }^{68}$ See: „611. § (2) Ein Schiedsspruch ist aufzuheben, wenn ... 4. die Bildung oder Zusammensetzung des Schiedsgerichts einer Bestimmung dieses Abschnitts oder einer zulässigen Vereinbarung der Parteien widerspricht." (An award shall be set aside if:...4 the constitution or composition of the arbitral tribunal was not in accordance with a provision of this part or an admissible agreement of the parties.)

${ }^{69}$ Cf.: Power: The Austrian Arbitration... op. cit. 115.

${ }^{70}$ Sub-point d. of Point 1 of Par. 2 of Art. 1059 of the German Code of Civil Procedures provides: „\$. 1059. (2) Eins Schiedsspruch kann nur aufgehoben werden, wenn der Antragsteller begründet geltend macht, dass ... d) die Bildung des Schiedsgerichts oder 
The new Austrian arbitration law for the most part regulates the early termination of the mandate of arbitrators in the basis of the Model Law in Art. 590 of the ZPO. The mandate of an arbitrator terminates when the arbitrator withdraws from office, moreover the parties mutually agree on his termination. In accordance with Par. 2 of Art. 590 any of the parties may appeal to a court of law to request the termination of the mandate of the arbitrator in case the arbitrator becomes incapacitated to proceed with his task or he is in unjustified delay with the fulfilment of his obligations and the arbitrator does not withdraw from office, the parties cannot agree upon the termination of the mandate of the arbitrator, or the arrangements stipulated by the parties for this case does not prove successful. It is important that in case the arbitrator withdraws from office according to Par. 1 of Art. 590 or after the filing of a motion of challenge against him, does not mean the acceptance of any of the exclusion grounds or grounds listed in Par. 2 of Art. 590 This in fact provides an opportunity for the arbitrator to leave office without any possible further impeachments or even any loss of prestige. ${ }^{71}$

Art. 591 of the ZPO contains stipulations on the election of deputy arbitrators which are identical to the rules of the nomination and appointment of arbitrators. A deputy arbitrator is obviously elected in the case when the mandate of the previous arbitrator is terminated. Par. 2 of Art 591 of the ZPO includes a rule on reasonable and economical conduct of the proceedings, inasmuch in case unless otherwise agreed by the parties, arbitrators shall continue with the proceedings taking into account the insofar finished previous procedural stages and results, including the minutes of the hearings. Naturally at the consideration of previous minutes-which were created in the presence of the arbitrator who left the tribunal-it is advisable to regard the grounds on which the arbitrator left office, this could affect the later evaluation of these minutes as well. It should be noted that this above explained rule of Par. 2 of Art. 591 of the ZPO cannot be found in the Model Law. (This provision is missing from the Hungarian Act on Arbitration, the Act LXXI of 1994, too.)

das schiedsrichterliche Verfahren einer Bestimmung dieses Buches oder einer zulässigen Vereinbarung der Parteien nicht entsprochen hat, und anzunehmen ist, dass sich dies auf den Schiedsspruch ausgewirkt hat...". The official translation of the German text: "1059. (2) An arbitral award may be set aside only if the applicant shows sufficient cause that ... d) the composition of the arbitral tribunal or the arbitral procedure was not in accordance with a provision of this Book or with an admissible agreement of the parties and this presumably affected the award." See: Berger, K. P.: The New German Arbitration Law in International Perspective. Forum Internationale, 26 (2000) 36.

${ }^{71}$ For this see: Power: The Austrian Arbitration... op. cit. 41. 
Summarizing the above written it can be emphasized that the new Austrian arbitration legal regulation differs from the earlier regulation on numerous points. In the matter of the nomination and exclusion of arbitrators the current Austrian rules contain more provisions which were not included in the older regulation and which we intended to sum up above.

Austrian legislators have taken into account to a great extent the Model Law in the framing of this legal regulation, yet there are numerous important questions even from the point of our theme where a different set of rules apply. The new Austrian arbitration rules obviously purpose to make proceedings smoother and more effective. The interpretation of the law by the legal practice will be obviously determined by the case law developed on the basis of these provisions. At the same time it is essential to refer to that the practice of law in its judgement of independence and impartiality will definitely take into account the case law born under the earlier regulation too, being an other reason why we deemed the comparison of the earlier legal rules and judicature with the current provisions law important.

IV.

As stated before, one of the most important arbitration institution in Austria is the International Arbitral Centre of the Austrian Federal Economic Chamber. For this end, it is justified to give a short analysis of the rule pertaining to the arbitration.

The Rules of Arbitration currently in force were accepted by the expanded presidency of the Austrian Federal Economic Chamber on ${ }^{\text {rd }}$ March 2006, and entered into force $1^{\text {st }}$ July 2006 at the same time as the ZPO novel, replacing the older rules of proceedings accepted by the general assembly of the Austrian Federal Economic Chamber on $30^{\text {th }}$ November 2000 and entered into force $1^{\text {st }}$ January $2001 .^{72}$

The so-called new Vienna Rules were framed in accordance with the above reviewed reform of arbitration law. Art. 7 deals with the appointment of arbitrators. According to Point 1 of Art. 7 the parties are free to agree in appointing the arbitrators. Any person having legal capacity-irrespective of nationality-may be an arbitrator, provided the parties have not agreed upon any special additional qualification requirements. This later provision was missing from the Vienna Rules in force till $30^{\text {th }}$ June 2006, Point 1 of Art. 5 thereof did not contain any information on the qualification of arbitrators. At

${ }^{72}$ Both rules of proceedings can be found at www.wko.at/arbitration. 
the same time the previous rules which were in force till $1^{\text {st }}$ January 2000 provided that arbitrators shall possess legal, commercial and other, relevant scientific qualifications and experience. ${ }^{73}$ The current procedural rules trust fully on the discretion parties whether arbitrators shall possess special knowledge or experience, the rules of proceedings only grants the possibility that parties may agree upon this question as well.

The currently in force Vienna Rules provide in relation with the nomination of arbitrators that they are to make a written statement as to their impartiality and independence, moreover that they submit themselves to the Vienna Rules of Arbitration. This requirement-also known to other international rules of arbitration-was missing form the former set of rules, it only contained the principle of the requirements of independence and impartiality. ${ }^{74}$

The current Vienna Rules-contrary to the earlier rules-prescribe in Point 5 of Art. 7 a disclosure requirement on the independence and impartiality of arbitrators. This rule is based on Par. 1 of Art. 588 of the ZPO and Par. 1 of Art. 12 of the Model-act with the following differences.

Contrary to the provisions of the ZPO, Point 5 of Art. 7 of the Vienna Rules follows the Model-act in respect that the disclosure obligation of the arbitrator is sets in when he is approached in connection with his possible appointment, and not when he is about to accept the office. On the other hand Vienna Rules follow the ZPO inasmuch the arbitrator shall disclose any circumstances likely to give rise to doubts as to his impartiality or independence, while the Model Law-as we noted above-prescribes this obligation in case of a well-founded doubt. According to the Vienna Rules the arbitrator shall disclose any circumstances hat are in conflict with the agreement of the parties.

Point 3 of Art. 7 of the current Vienna Rules-similar to previous regulations-includes that very important rule which a member of the Presidency Board of the Arbitral Centre may act only as Chairman of an arbitral tribunal or sole arbitrator. ${ }^{75}$

In relation to the nomination of arbitrators it should be underlined that pursuant to the Vienna Rules, either a sole arbitrator or an arbitral tribunal consisting of three arbitrators shall proceed. When no such agreement has been made and the parties do not agree on the number of arbitrators, the Board shall

\footnotetext{
${ }^{73}$ See: Oppenheim, K.: Választottbíróság Ausztriában. (Arbitration Court in Austria.) Magyar Jog, 40 (1993) 733.

${ }^{74}$ The Rules of Proceedings of ICC (International Chamber of Commerce) prescribe a similar statement requirement in Par. 2 Art. 7, furthermore Article 5.3 of the Rules of Proceedings of the London LCIA (London Court of International Arbitration).

${ }^{75}$ In relation to this see: Baier-Trofaier: Austria. op. cit. 23.
} 
determine whether the dispute is to be decided by a sole arbitrator or by an arbitral tribunal on the basis of Point 2 of Art. 14 of the Vienna Rules. In that context, the Board shall take into consideration in particular the difficulty of the case, the magnitude of the amount in dispute and the interest of the parties in a rapid and cost-effective decision. In the event that proceedings before a sole arbitrator are decided upon, the parties shall be requested to agree on a sole arbitrator within thirty days after service of the request. In the lack of such agreement the arbitrator shall be appointed by the Board.

Point 4 of Art. 14 of the Vienna Rules prescribes that if the dispute is to be decided by an arbitral tribunal, and the party that has not yet nominated an arbitrator within thirty days, then the arbitrator shall be appointed by the Board. This point has been changed significantly since previous rules. Point 4 of Art. 9 of the earlier Rules of Proceedings applied a distinction between the claimant and defendant in this question containing a serious consequence. If the Claimant has not appointed an arbitrator within 30 days after service of notice and does not expressly leave the appointment to the Board, the case must be deleted from the list of pending cases, and only if the Defendant fails to appoint an arbitrator within that time-limit, shall the arbitrator be automatically appointed by the Board. Thus earlier rules demonstrated more vigorously in this respect that fundamentally it is in the sphere of interest of the claimant that the arbitration proceedings are conducted.

The challenge of arbitrators is stipulated in Art. 16 of the Vienna Rules. Paragraph 1 of Article 16 follows Par. 2 of Art. 588 of the ZPO and Par. 2 of Art. 12 of the Model-act with the difference that while these later set of rules the lack of qualification agreed by the parties establishes a ground of exclusion, pursuant to the Vienna Rules-along with the doubt arisen in relation with the question of independence or impartiality-circumstances that are in conflict with the agreement of the parties produce a ground of exclusion. Vienna Rules stipulate similar to the ZPO and the Model-act that under what conditions is a party entitled to challenge an arbitrator in whose appointment this party participated.

In this relation the current Vienna Rules contain a more precise provision than earlier ones. Point 1 of Art. 11 of the earlier Rules of Proceedings included laconically that an arbitrator may be challenged if there are sufficient grounds for doubting his independence or impartiality. ${ }^{76}$

\footnotetext{
${ }^{76}$ It should be noted that according to previous rules-pursuant to Point 3 of Art. 11 of the Rules of Proceedings-a challenge is inadmissible if the party making the challenge has taken part in the proceedings notwithstanding the knowledge which it already had or ought
} 
Points 2, 3 and 4 of Article 16 apply on the rules of challenge. If a party challenges an arbitrator, it must without delay inform the Secretary General thereof, stating the grounds for the challenge. Should the challenged arbitrator not withdraw from his office, the Board shall decide upon the challenge on the basis of the particulars in the challenging motion and the evidence attached thereto. Before the Board makes its decision, the Secretary General must obtain the comments of the arbitrator challenged and of the other parties. The Board can also request comments from other persons.

In spite of the motion of challenge the arbitral proceedings may continue. It is important however that an award may not be rendered until after the final and binding decision of the Board. Nevertheless, we should be aware here of Point 3 of Art. 589 of the act on arbitration, on the basis thereof an unsuccessful procedure of challenge can be appealed. ${ }^{77}$

The current Vienna Rules contain in relation to the exclusion new stipulations which were missing from earlier set of rules. Article 21 of the prevailing Vienna Rules allows that rules applicable to the challenging of arbitrators shall apply accordingly to the challenging of experts appointed by the sole arbitrator or by the arbitral tribunal. The challenge of experts shall be decided on by the sole arbitrator or by the arbitral tribunal.

These provisions of the Vienna Rules cannot be described as exclusive in the field of international commercial arbitration. It deserves special notice that we can find similar decisions in Swiss case law. In one case the Supreme Court of Switzerland has extended the requirements of impartiality and independence onto experts appointed by the arbitral tribunal. ${ }^{78}$

In the light of the above written it is unmistakably clear that the new Vienna Rules intend to comply to a great extent with the rules of Austrian arbitration law in force since $1^{\text {st }}$ July 2006 . At the same time it is important that the rules of arbitration of the chamber preserved numerous particular features in subject matter of nomination and challenging of arbitrators. The new Vienna Rules and the practice of law relying on them will presumably contribute significantly to that the several entities of international economy in the future will choose Vienna as the and the International Arbitral Centre of the Austrian Federal Economic Chamber place of arbitration and place of the settlement of their legal disputes as well.

to have had of the grounds of challenge relied upon, or if the party making the challenge notified the grounds of challenge with undue delay.

${ }^{77}$ For this see: Zeiler-Steindl: The New Austrian Arbitration... op. cit. 47.

${ }^{78}$ See: BG (Bundesgerichtshof) 28. 04. 2000. The resolution is quoted by: Liebscher: The Healthy Award. op. cit. 274. 